\title{
Workforce Management Evaluation at Adinda Parinring Kindergarten Makassar
}

\author{
Sofyan, Arifuddin Siraj, Mardyawati \\ Pascasarjana UIN Alauddin Makssar \\ Email: fhyank17@gmail.com
}

(Received: March 26-2019; revised: March 28-2019; published: May 31-2019)

\begin{abstract}
This study describes how the Workforce management evaluation at Adinda Parinring Makassar kindergarten is specifically the implementation of the management of the teaching staff. To obtain answers to these problems, the authors use three methods of data collection; Observations, interviews and documentation. In field research the author uses observation and interview instruments. Qualitative data processing and data analysis techniques that I use are; Data reduction, data discovery and data verification. The samples in this study were all educators in Adinda Parinring Makassar kindergarten. The results of the study show that the evaluation and follow-up of educators in Adinda Parinring Kindergarten are conducted regularly, ie every week and at the end of each semester.
\end{abstract}

Keywords: Evaluation; Workforce Management; Educators

\section{INTRODUCTION}

Education in the development process contributes greatly to the progress of a nation, because education is a means of building national character. According to (Vibulphol, 2016), program policies to improve the quality of education include three main aspects, namely: first, the development of a sustainable curriculum at all levels and types of education. Second, improve the welfare and professionalism of teachers. Third, the utilization of educational facilities and infrastructure. Meanwhile, according to Mulyadi, education basically has the objectives to be achieved and to realize it, it needs to be supported by a clear curriculum, learning, human resources, facilities and infrastructure, funds, information, and a conducive environment managed through a systematic process (Farida, 2017; Kamaluddin, Haerul, Akib, \& Salam, 2018; Saggaf, Nasriyah, Salam, \& Wirawan, 2018; Saggaf, Salam, \& Rifka, 2017; Salam, Akib, \& Daraba, 2018).

In terms of workforce (teacher), the low quality of teachers is a fundamental problem that can hinder the development and development of educational institutions (Akib \& Saleh, 2015; Amaliyah, Akib, \& Tambe, 2015). Therefore, qualified human resources (teachers) are needed that have the willingness and ability to continuously improve their quality continuously and continuously (Akib \& Saleh, 2015; Amaliyah et al., 2015; Idzhar, 2016; Megawati \& Kahar, 2017).

Improving teacher quality is an absolute requirement for achieving educational development goals. The quality of teachers is enhanced through a variety of educational programs that are systematic and directed based on the interests that refer to the advancement of science and technology (Science and Technology) based on faith and piety (IMTAQ). 


\author{
72| Jurnal Ilmiah Ilmu Administrasi Publik: Jurnal Pemikiran dan Penelitian Administrasi Publik \\ Volume 9 Number 1, January - June 2019. Page 71-76
}

In an effort to improve the quality of teachers, a mechanism is needed that is able to regulate and optimize various components and existing resources. One effort to improve teacher quality or employment in schools is by conducting evaluations as a quality management direction. Seeing the importance of evaluating HR management (workforce) as part of management education, the author intends to examine the evaluation of management management in this case is the teacher at the Adinda Parinring Makassar Kindergarten.

Kindergarten Adinda Parinring Makassar is one of the early education institutions in Makassar. Where educators in Adinda Parinring Makassar Kindergarten have resources that must be controlled as an effort to improve teacher quality or staff. Ideally at every level of education, the teaching staff must teach in accordance with the scientific field that is mastered. So it takes an evaluation of each program that has been implemented.

\title{
METHOD
}

This type of research is qualitative research on the grounds that the object under study requires accurate data in the form of descriptive data, namely written data obtained from various sources such as several informants, phenomena, documentation, or certain events, both individually and in groups. This research was carried out in Adinda Parinring Makassar kindergarten, having its address at Jalan Tamangapa Raya V No. 48 C, Tamangapa Village, Manggala District, Makassar City.

The data sources in this study are all data or people who provide information and information relating to research needs. There are 2 sources of data used primary data and secondary data. Primary data is the source of data obtained or collected directly by researchers from the object of research in the field, primary data obtained from informant sources namely individuals or individuals as the result of interviews conducted by researchers to informants. The primary data sources in this study were the principal and 3 educators in the Adinda Parinring Makassar kindergarten. Secondary data sources are data that is obtained or collected by people who conduct research from existing sources. This data is used to support primary information that has been obtained, namely from library materials, literature, previous research, books, and so forth. Secondary data sources in this study are school profiles, bulletin boards, school structure boards and others that can support primary data.

The technique used in data collection is observation, interviews and documentation. The analysis technique used in this study refers to the concepts of (Miles, Huberman, \& Saldaña, 2014), there are four steps in analyzing data, namely: (1) Data reduction, data condensation, data presentation and conclusion drawing.

\section{RESULT AND DISCUSSION}

Improving the quality of education is determined by the preparedness of human resources involved in the education process. The teacher is one of the determinants of the high and low quality of education outcomes that have a strategic position so that every effort to improve the quality of education needs great attention to the improvement of teachers both in terms of quantity and quality. 
The teacher is an element that greatly influences the achievement of the goals of education in schools other than students and other facilities. The teacher's presence in the learning process at school still plays an important role. The teacher is a very dominant and most important factor in formal education in general because for students teachers are often used as role models for themselves. The success of the implementation of education is very much determined by the readiness of teachers to prepare their students through teaching and learning activities. However, the teacher's strategic position to improve the quality of education outcomes is strongly influenced by the professional ability of the teacher and the quality of his performance (Awaru, 2015; Nasrullah, Rumingan, Nasaruddin, \& Niswaty, 2017).

The teacher is the spearhead of educational and learning activities that become a motivator for students in spurring learning activities of students in school. Therefore, the teacher's ability to teach is demanded to always increase in line with the advancement of science and technology so that the teaching and learning interaction activities are increasingly alive (Vibulphol, 2016).

To improve teacher performance, one way to evaluate its performance is by making meetings and confiding in opinions followed by the principal, teacher, all staff, committee members, or also the foundation. The principal becomes the leader of the meeting and starts with the question: do we need to improve the quality? What is the condition of our school in terms of quality at this time? Why is our school not qualified? This self-evaluation activity is a self-reflection to raise awareness of the importance of quality education, thus giving rise to a shared commitment to improve quality, and formulate a starting point for schools to develop themselves, especially the quality of education. 15

Data from interviews with Ms. Resky Amelia as the school principal stated that the evaluation phase of educators in kindergarten Adinda Parinring Makassar was conducted every week, I as the principal of Adinda Parinring Makassar Kindergarten traveled to each class to see the interaction process between the teacher and students to be able to evaluate the teaching staff about what things need to be addressed in the way they teach or the learning media, and also maintain the good things that have been applied by the teaching staff (Salam et al., 2018).

Interviewing Masita said that the principal does not only hold meetings every weekend but also holds meetings every semester to assess the teacher's performance each semester. At the semester meeting not only discussing teacher performance but discussing the planning of the next semester (Cooley \& Larson, 2018).

So the performance evaluation stage of the educators in kindergarten Adinda Parining Makassar is done every week, and also every end of the semester. By holding a meeting and discussing the shortcomings and advantages that must be and remain maintained by the teacher. This effort is carried out by the principal so that the teacher can further develop their own potential so that they are more advanced in the future.

Furthermore, as a result of the interview, Nurwahida stated that not only were we educators who were given input or criticism from the principal, but we also sometimes evaluated the principal by giving input to better improve school management so that in the future it would be better (Mistrianingsih, Imron, \& Nurabadi, 2016).

The conclusions that can be drawn from the results of the interview above are the evaluation process and follow-up carried out by Adinda Parinring Kindergarten in Makassar. They have carried out several evaluation and follow-up processes to their educators and 
$74 \mid$ Jurnal Ilmiah Ilmu Administrasi Publik: Jurnal Pemikiran dan Penelitian Administrasi Publik Volume 9 Number 1, January - June 2019. Page 71-76

principals as leaders, by which the main school principal can maintain and develop this so that the school is more qualified.

\section{CONCLUSION}

The evaluation and follow-up process carried out by Adinda Parinring Kindergarten in Makassar has carried out several evaluation and follow-up processes for its teaching staff as well as the principal as a leader.

\section{REFERENCES}

Akib, H., \& Saleh, S. (2015). Pengaruh Kepala Sekolah Sebagai Supervisor Terhadap Kinerja Guru Di Smk Negeri 7 Makassar. Jurnal Office, 1(2), 141-147.

Amaliyah, R., Akib, H., \& Tambe, M. N. (2015). Pengaruh Metode Mengajar Bervariasi Guru Terhadap Motivasi Belajar Siswa Pada Jurusan Administrasi Perkantoran Smk Negeri 1 Makassar. Jurnal Office, 1(2), 198-205.

Awaru, O. T. (2015). Pengaruh Gaya Kepemimpinan Transaksional dan Transformasional Terhadap Kinerja Guru SMA di Kabupaten Sinjai. Jurnal Ad'ministrare, 2(1), 27-35.

Cooley, J. H., \& Larson, S. (2018). Promoting a growth mindset in pharmacy educators and students. Currents in Pharmacy Teaching and Learning, 10(6), 675-679. https://doi.org/https://doi.org/10.1016/j.cptl.2018.03.021

Farida, U. (2017). Analysis of Empowerment Program that was Implemented in Mamuju Regency East Sulawesi Indonesia. 149(Icest), 19-21.

Idzhar, A. (2016). Peranan Guru dalam Meningkatkan Motivasi Belajar Siswa. Jurnal Office, 2(2), 221-228.

Kamaluddin, L. O. A., Haerul, H., Akib, H., \& Salam, R. (2018). Analysis Of Factors Influencing Student Learning Achievement.

Megawati, M., \& Kahar, F. (2017). Pengaruh Komunikasi Orang Tua Dengan Guru terhadap Peningkatan Kualitas Pembelajaran. Jurnal Office, 3(1), 33-42.

Miles, M. B., Huberman, A. M., \& Saldaña, J. (2014). Qualitative data analysis: A methods sourcebook. 3rd. Thousand Oaks, CA: Sage.

Mistrianingsih, S., Imron, A., \& Nurabadi, A. (2016). Peran Kepala Sekolah dalam Implementasi Manajemen Berbasis Sekolah. Manajemen Pendidikan, 25, 103-111. 
Nasrullah, M., Rumingan, M., Nasaruddin, N., \& Niswaty, R. (2017). Pengaruh Pengambilan Keputusan Kepala Sekolah terhadap Kinerja Guru di SMK Negeri 1 Makassar. Jurnal Ad'ministrare, 4(2), 103-110.

Saggaf, M. S., Nasriyah, N., Salam, R., \& Wirawan, H. (2018). The Influence of Teacher's Pedagogic Competence on Learning Motivation of Student of Office Administration Expertise Package.

Saggaf, M. S., Salam, R., \& Rifka, R. (2017). The Effect of Classroom Management on Student Learning Outcomes. International Conference on Education, Science, Art and Technology, 98-102.

Salam, R., Akib, H., \& Daraba, D. (2018). Utilization of Learning Media In Motivating Student Learning. 1st International Conference on Social Sciences (ICSS 2018). Atlantis Press.

Vibulphol, J. (2016). Students' Motivation and Learning and Teachers' Motivational Strategies in English Classrooms in Thailand. English Language Teaching, 9(4), 64-75. 
76| Jurnal Ilmiah Ilmu Administrasi Publik: Jurnal Pemikiran dan Penelitian Administrasi Publik Volume 9 Number 1, January - June 2019. Page 71-76 